\title{
Late Effect of Early Hypoxic Disturbance in the Rat Heart: Gender Differences
}

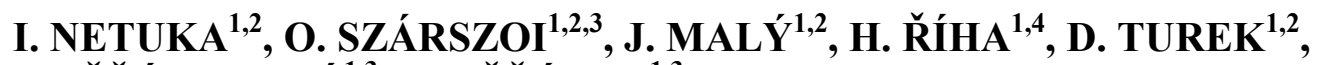 \\ I. OŠŤÁDALOVÁ ${ }^{1,3}$, B. OŠŤÁDAL ${ }^{1,3}$
}

${ }^{1}$ Centre for Cardiovascular Research, Prague, Czech Republic, ${ }^{2}$ Department of Cardiovascular Surgery, Institute for Clinical and Experimental Medicine, Prague, Czech Republic, ${ }^{3}$ Institute of Physiology, Academy of Sciences of the Czech Republic, Prague, Czech Republic, and ${ }^{4}$ Department of Anaesthesiology and Intensive Care Medicine, Prague, Czech Republic

Received June 19, 2009

Accepted October 14, 2009

\begin{abstract}
Summary
Perinatal hypoxemia may have serious long-term effects on the adult cardiovascular system and may lead to sex-dependent changes in cardiac tolerance to acute ischemia in adult life. The aim of the study was to answer the question whether gonadectomy of the male and female rats in the early phase of ontogenetic development affects the late effect of perinatal hypoxia. Pregnant Wistar rats were placed into a normobaric hypoxic chamber $\left(12 \% \mathrm{O}_{2}\right) 7$ days before the expected date of delivery. Newborn pups were kept in the chamber with their mothers for another 5 days after birth. After hypoxic exposure all animals were kept for 3 months in room air. Some of the pups were gonadectomized right after removal from the hypoxic chamber. Ventricular arrhythmias were assessed on isolated perfused hearts. Castration did not influence arrhythmogenesis in the adult normoxic or perinatally hypoxic female hearts. Nevertheless, the number of arrhythmias was decreased in perinatally hypoxic gonadectomized males. In conclusion, we have shown that perinatal normobaric hypoxia increased cardiac tolerance to acute ischemia in adult male rats; however, it had no late effect in females. Gonadectomy did not affect arrhythmogenesis in both normoxic and hypoxic female hearts, whereas in males significantly decreased the number of arrhythmias.
\end{abstract}

\section{Key words}

Perinatal hypoxia - Gender • Isolated rat heart • Ischemia/reperfusion injury

\section{Corresponding author}

Ondrej Szárszoi, Department of Cardiovascular Surgery, Institute for Clinical and Experimental Medicine, Vídeňská 1958/9, 14021 Prague 4, Czech Republic. Phone: 420261083 375; Fax: 420 261081 362. E-mail: onsz@medicon.cz

The evidence that perinatal hypoxemia may have serious long-term effects on the adult cardiovascular system is increasing in the last years (Rohlicek et al. 2002, Li et al. 2003, 2004). This fact is in accordance with Barker's concept of fetal and neonatal programming, which is based on epidemiological studies showing that perinatal pathogenetic factors may be linked with the development of adult cardiovascular diseases (Barker 2000). According to $\mathrm{Li}$ et al. (2003, 2004), prenatal chronic hypoxia increased the susceptibility of the 6-month-old male rat heart to ischemia/reperfusion injury. Nevertheless, prenatal hypoxia was without any effect on infarct size in young, 2-month-old male hearts. Using the model of perinatal exposure to daily intermittent hypobaric hypoxia (IHH) we have demonstrated that hypoxia changes the tolerance of the adult rat myocardium to acute ischemic damage; this phenomenon was gender-dependent (Netuka et al. 2006). The aim of the present study was, therefore, to answer the question whether gonadectomy of the male and female rats performed during early phase of ontogenetic development may moderate cardiac resistance to ischemia/reperfusion injury in adult animals. 
Table 1. Coronary flow, perfusion pressure and heart rate of the isolated perfused hearts in normoxic and perinatally hypoxic control and gonadectomized male and female rats before ischemia and after the first min of ischemia and reperfusion.

\begin{tabular}{|c|c|c|c|c|c|c|c|c|}
\hline & $\mathbf{n}$ & $\begin{array}{l}\text { Coronary } \\
\text { flow }\end{array}$ & $\begin{array}{l}\text { Perfusion pre } \\
\text { stabilisation }\end{array}$ & $\begin{array}{l}\text { essure }(\mathrm{mmHg}) \\
\text { ischemia } \\
1 \mathrm{~min}\end{array}$ & $\begin{array}{l}\text { reperfusion } \\
1 \mathrm{~min}\end{array}$ & $\begin{array}{l}\text { Heart rate ( } n \\
\text { stabilisation }\end{array}$ & $\begin{array}{l}\left.\operatorname{lin}^{-1}\right) \\
\text { ischemia } \\
1 \mathrm{~min}\end{array}$ & $\begin{array}{l}\text { reperfusion } \\
1 \mathrm{~min}\end{array}$ \\
\hline \multicolumn{9}{|l|}{ Males } \\
\hline Normoxic & 17 & $13.1 \pm 0.6$ & $54.6 \pm 4.1$ & $74.2 \pm 5.3^{*}$ & $57.6 \pm 3.0$ & $265 \pm 9$ & $283 \pm 12$ & $274 \pm 19$ \\
\hline Hypoxic & 14 & $13.7 \pm 0.6$ & $58.6 \pm 4.3$ & $85.1 \pm 11.2^{*}$ & $57.5 \pm 2.9$ & $237 \pm 6$ & $260 \pm 12$ & $249 \pm 17$ \\
\hline $\begin{array}{l}\text { Gonadectomized } \\
\text { normoxic }\end{array}$ & 10 & $12.8 \pm 0.9$ & $51.9 \pm 5.1$ & $68.4 \pm 8.3^{*}$ & $57.8 \pm 6.2$ & $272 \pm 9$ & $292 \pm 19$ & $269 \pm 25$ \\
\hline $\begin{array}{l}\text { Gonadectomized } \\
\text { hypoxic }\end{array}$ & 11 & $12.8 \pm 0.9$ & $60.3 \pm 8.2$ & $83.6 \pm 14.0^{*}$ & $61.4 \pm 4.9$ & $248 \pm 10$ & $256 \pm 12$ & $271 \pm 18$ \\
\hline \multicolumn{9}{|l|}{ Females } \\
\hline Normoxic & 11 & $11.4 \pm 0.5$ & $39.1 \pm 2.6^{\ddagger}$ & $53.3 \pm 3.8^{*}$ & $45.9 \pm 3.1^{\ddagger}$ & $262 \pm 7$ & $269 \pm 11$ & $256 \pm 19$ \\
\hline Hypoxic & 11 & $12.6 \pm 0.5^{+}$ & $53.4 \pm 5.3^{+}$ & $74.6 \pm 7.3^{*^{+}}$ & $59.9 \pm 5.9^{+}$ & $259 \pm 10$ & $276 \pm 19$ & $287 \pm 20$ \\
\hline $\begin{array}{l}\text { Gonadectomized } \\
\text { normoxic }\end{array}$ & 10 & $12.9 \pm 0.8$ & $52.3 \pm 5.3$ & $70.1 \pm 6.9^{*}$ & $59.2 \pm 5.5$ & $263 \pm 13$ & $267 \pm 15$ & $276 \pm 34$ \\
\hline $\begin{array}{l}\text { Gonadectomized } \\
\text { hypoxic }\end{array}$ & 8 & $13.0 \pm 1.2$ & $58.4 \pm 8.0$ & $87.1 \pm 18.4^{*}$ & $60.1 \pm 6.6$ & $255 \pm 10$ & $269 \pm 15$ & $272 \pm 35$ \\
\hline
\end{tabular}

$\mathrm{n}$, number of animals. Values are mean $\pm \mathrm{SEM} .{ }^{*} \mathrm{P}<0.05$ vs. pre-ischemic value, ${ }^{\ddagger} \mathrm{P}<0.05$ female vs. male, ${ }^{+} \mathrm{P}<0.05$ hypoxic vs. normoxic.

The investigations were performed in accordance with the Guide for Care and Use of Laboratory Animals published by the US National Institutes of Health (NIH Publication No. 85-23, revised 1996). For better simulation of perinatal hypoxic condition in clinical practice, perinatal normobaric hypoxia $(\mathrm{NH})$ was used. Pregnant Wistar rats were placed into a normobaric hypoxic chamber $\left(12 \% \mathrm{O}_{2}\right) 7$ days before the expected date of delivery. Newborn pups were kept in chamber with their mothers for another 5 days after birth. After hypoxic exposure all animals were kept for 3 months in the room air. Some of the pups were gonadectomized immediately after removal from the hypoxic chamber using the deep ether anesthesia (Oštádalová and Pařízek 1968). Sham surgery was performed under identical conditions as the gonadectomy. Ischemic arrhythmias were measured on the isolated hearts perfused according to Langendorff under constant flow with the non-recirculating Krebs-Henseleit solution. After 25-min stabilization, regional 30-min no-flow ischemia was induced by the LAD coronary artery occlusion (for details see Szarszoi et al. 2001). Ventricular arrhythmias during ischemic insult were assessed according to the Lambeth Conventions (Walker et al. 1988). The results are expressed as means \pm S.E.M.
One-way ANOVA or ANOVA for repeated measures and subsequent Student-Newman-Keuls test were used for comparison of differences between groups. Differences were assumed as statistically significant when $\mathrm{P}<0.05$.

Body weight (BW) and heart weight (HW) of normoxic, perinatally hypoxic and gonadectomized adult female rats were significantly lower as compared with age-matched male animals. Gonadectomy significantly decreased BW in normoxic and hypoxic male rats, whereas in both groups of females BW was increased; there were no differences between normoxic and perinatally hypoxic gonadectomized rats. HW was lower in all female groups as compared to males. Perfusion pressure and heart rate before ischemia and during ischemia and reperfusion are summarized in Table 1. None of the hearts exhibited ventricular arrhythmias during the preischemic phase. Castration and perinatal hypoxia did not influence arrhythmogenesis in adult female hearts. On the other hand, the number of premature ventricular complexes occurring as singles, salvos and ventricular tachycardia as well as the total number of arrhythmias was significantly decreased in perinatally hypoxic and gonadectomized males (Fig. 1).

Our results have shown that strong insult in the neonatal period like castration and $\mathrm{NH}$ has no late effect 

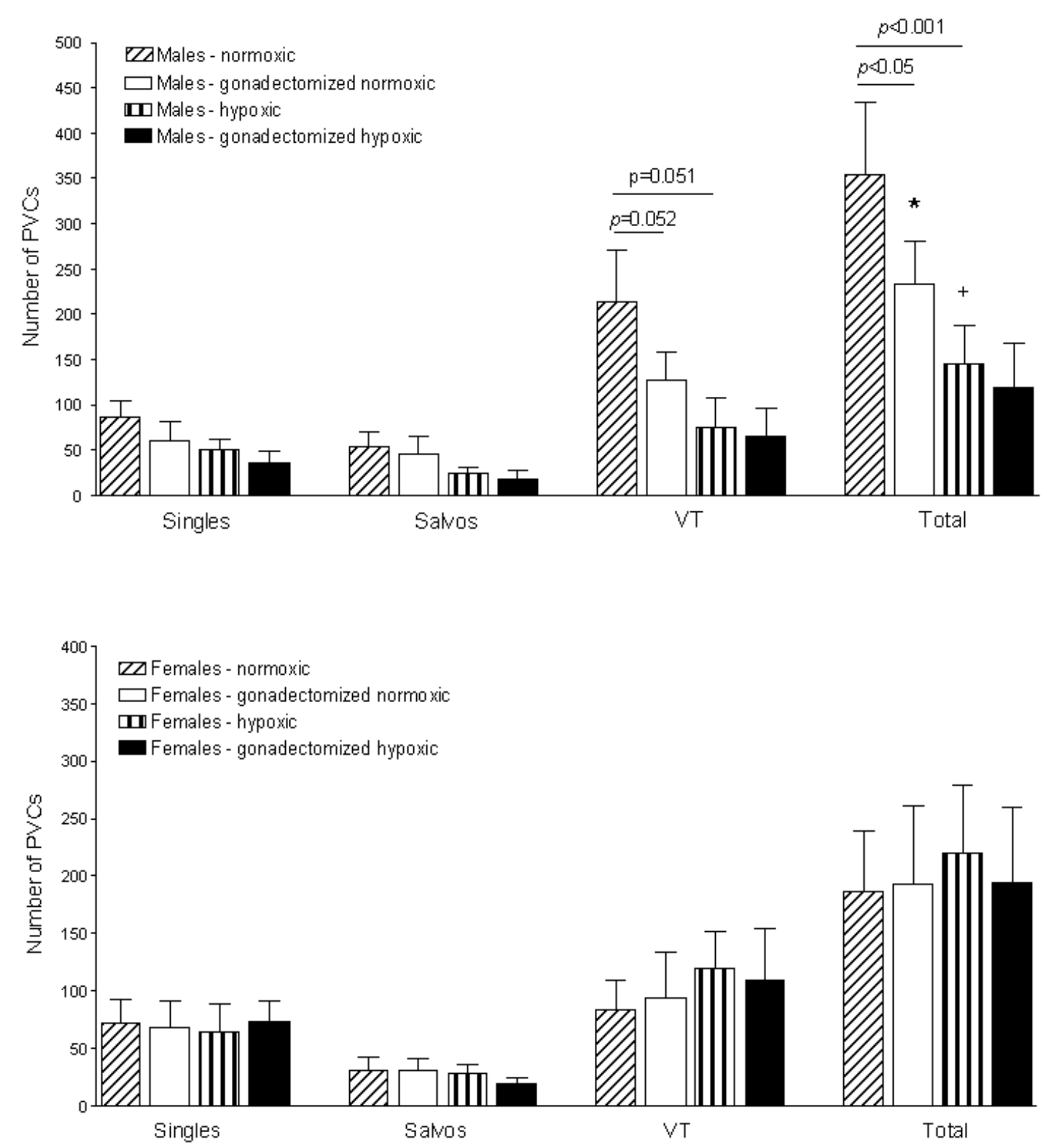

Fig. 1. Premature ventricular complexes (PVCs) occurring as singles, salvos and ventricular tachycardia (VT), total number of PVCs during 30-min coronary artery occlusion in the normoxic and perinatally hypoxic control and gonadectomized adult male (upper) and female (bottom) rats. Values are means $\pm \mathrm{SEM},{ }^{*} P<0.05$ gonadectomized vs. corresponding control, ${ }^{+} P<0.05$ hypoxic vs. normoxic.

on the arrythmogenesis in adult females. On the other hand, gonadectomy as well as perinatal hypoxia significantly decreased ischemic arrhythmias in the adult males. Interestingly, in comparison with our previous study, the late effect of perinatal hypoxia on male and female myocardium is different. We have previously observed that perinatal exposure to IHH significantly increased cardiac tolerance to acute ischemic injury in adult females, expressed as the incidence of ischemic arrhythmias and reduced LDH. The effect of IHH on ischemic arrhythmias in males was quite opposite (Netuka et al. 2006). The explanation should probably be searched in the different types of hypoxia. Nevertheless, data from literature comparing the effect of normobaric and hypobaric hypoxia are very rare. Experimental studies focusing on late effects of early hypoxia used different types of hypoxia, e.g. Rohlicek et al. (2002) used hyperbaric hypoxia, whereas Li et al. (2003, 2004) and Hampl et al. (2003) used permanent NH. The comparison of the results in this situation (different types of hypoxic cycles and degree of hypoxia) is very difficult. Similarly, the data comparing intermittent and permanent hypoxia are poor. Farahani et al. (2008) have shown that postnatal IHH leads to significant body growth retardation and grater heart hypertrophy in comparison with permanent NH. Fan et al. (2005) observed that 
apoptosis was enhanced in the neonatal mouse heart exposed to permanent hypoxia but not to intermittent hypoxia and this was correlated with an upregulation of proapoptotic genes and downregulation of anti-apoptotic genes in permanent hypoxia. In addition, there are only a few papers dealing with the gonadectomized male and female animals in the long-term effect of perinatal $\mathrm{NH}$. Hampl and Herget (1990) and Hampl et al. (2003) found that ovariectomy at a very young age greatly augmented the effects of perinatal hypoxia in females, so that pulmonary arterial pressure in adulthood was significantly increased.

The question remains what is the cause of the gender difference in cardiac sensitivity to ischemia. A large body of evidence indicates that estrogen is involved in gender-related mechanisms of ischemia tolerance. Along with their well-known "genomic" effects, additional processes termed "non-genomic" occur rapidly and independently of protein synthesis (Di Lisa 2006). Among the many pathways that can modify the susceptibility to ischemic injury in female hearts is nitric oxide (Sun et al. 2006), sarcolemmal (Johnson et al. 2006) and mitochondrial $\mathrm{K}_{\mathrm{ATP}}$ channels (Lee et al. 2000), protein kinase $\mathrm{B}(\mathrm{Akt})$ and protein kinase $\mathrm{C} \varepsilon$ levels (Bae and Zhang 2005) or tumor necrosis factor $\alpha$ (Xu et al. 2006). Nevertheless, the cardiovascular system is influenced not only by estrogens, but at least by one additional player - androgens. Similarly to estrogens, androgens are present in both sexes, albeit at different concentrations and ratios. However, the influence of testosterone on cardiovascular system is still controversial; experimental studies have shown its positive as well as negative effect on cardiac sensitivity to oxygen deprivation (for review see Ošt'ádal et al. 2009).

In conclusion, we have shown that perinatal exposure to $\mathrm{NH}$ increased cardiac tolerance to acute ischemic injury in adult male rats. However, permanent $\mathrm{NH}$ had no late effect in females. Gonadectomy did not affect arrhythmogenesis in both normoxic and hypoxic female hearts, whereas in males significantly influenced the incidence of arrhythmias in adulthood. Our results support the hypothesis that hypoxia in the early stages of ontogenesis is a programming stimulus leading to genderdependent changes in cardiac tolerance to ischemia in later adult life.

\section{Conflict of Interest}

There is no conflict of interest.

\section{Acknowledgements}

This study was supported by grant from the Ministry of Education of the Czech Republic 1M0510, grant AV0Z 50110509, and grant of the Czech Ministry of Health, Nr. 0000064203.

\section{References}

BAE S, ZHANG L: Gender differences in cardioprotection against ischemia/reperfusion injury in adult rat hearts: Focus on Akt and protein kinase C signaling. J Pharmacol Exp Ther 315: 1125-1135, 2005.

BARKER DJ: In utero programming of cardiovascular disease. Theriogenology 53: 555-574, 2000.

DI LISA F: A female way to protect the heart. Say NO to calcium. Circ Res 98: 298-300, 2006.

FAN C, IACOBAS DA, ZHOU D, CHEN Q, LAI JK, GAVRIALOV O, HADDAD GG: Gene expression and phenotypic characterization of mouse heart after chronic constant or intermittent hypoxia. Physiol Genomics 22: 292-307, 2005.

FARAHANI R, KANAAN A, GAVRIALOV O, BRUNNERT S, DOUGLAS RM, MORCILLO P, HADDAD GG: Differential effects of chronic intermittent and chronic constant hypoxia on postnatal growth and development. Pediatr Pulmonol 43: 20-28, 2008.

HAMPL V, HERGET J: Perinatal hypoxia increases hypoxic pulmonary vasoconstriction in adult rats recovering from chronic exposure to hypoxia. Am Rev Respir Dis 142: 619-624, 1990.

HAMPL V, BÍBOVÁ J, OŠŤÁDALOVÁ I, POVÝŠILOVÁ V, HERGET J: Gender differences in the long-term effects of perinatal hypoxia on pulmonary circulation in rats. Am J Physiol 285: L386-L392, 2003.

JOHNSON MS, MOORE RL, BROWN DA: Sex differences in myocardial infarct size are abolished by sarcolemmal $\mathrm{K}_{\mathrm{ATP}}$ channel blockade in rat. Am J Physiol 290: H2644-H2647, 2006.

LEE TM, SU SF, TSAI CC, LEE YT, TSAI CH: Cardioprotective effect of 17 beta-estradiol produced by activation of mitochondrial ATP-sensitive $\mathrm{K}^{+}$channels in canine hearts. J Mol Cell Cardiol 32: 1147-1158, 2000. 
LI G, XIAO Y, ESTRELLA JL, DUCSAY CA, GILBERT RD, ZHANG L: Effect of fetal hypoxia on heart susceptibility to ischemia and reperfusion injury in the adult rat. $J$ Soc Gynecol Investig 10: 265-274, 2003.

LI G, BAE S, ZHANG L: Effect of prenatal hypoxia on heat stress-mediated cardioprotection in adult rat heart. Am $J$ Physiol 286: H1712-H1719, 2004.

NETUKA I, SZÁRSZOI O, MALÝ J, BEŠÍK J, NECKÁŘ J, KOLÁŘ F, OŠŤÁDALOVÁ I, PIRK J, OŠŤÁDAL B: Effect of perinatal hypoxia on cardiac tolerance to acute ischaemia in adult male and female rats. Clin Exp Pharmacol Physiol 33: 714-719, 2006.

OŠŤÁDAL B, NETUKA I, MALÝ J, BEŠÍK J, OŠŤÁDALOVÁ I: Gender differences in cardiac ischemic injury and protection - experimental aspects. Exp Biol Med 234: 1011-1019, 2009.

OŠŤÁDALOVÁ I, PAŘÍZEK J: Delayed retardation of static growth of rats injected with oestrogens during the first days of postnatal life. Physiol Bohemoslov 17: 217-228, 1968.

ROHLICEK CV, MATSUOKA T, SAIKI C: Cardiovascular response to acute hypoxemia in adult rats hypoxemic neonatally. Cardiovasc Res 53: 263-270, 2002.

SUN J, PICHT E, GINSBURG KS, BERSDM, STEENBERGEN C, MURPHY E: Hypercontractile female hearts exhibit increased S-nitrosylation of the L-type $\mathrm{Ca}^{2+}$ channel alpha 1 subunit and reduced ischemia-reperfusion injury. Circ Res 98: 403-411, 2006.

SZÁRSZOI O, ASEMU G, VANĚČEK J, OŠŤÁDAL B, KOLÁŘ F: Effects of melatonin on ischemia and reperfusion injury of the rat heart. Cardiovasc Drugs Ther 15: 251-257, 2001.

WALKER MJ, CURTIS MJ, HEARSE DJ, CAMPBELL RW, JANSE MJ, YELLON DM, COBBE SM, COKER SJ, HARNESS JB, HARRON DW, HIGGINS AJ, JULIAN DG, LAB MJ, MANNING AS, NORTHOVER BJ, PARRATT JR, RIEMERSMA RA, RIVA E, RUSSELL DC, SHERIDAN DJ, WINSLOW E, WOODWARD B: The Lambeth Conventions: guidelines for the study of arrhythmias in ischaemia, infarction, and reperfusion. Cardiovasc Res 22: 447-455, 1988.

XU Y, ARENAS IA, ARMSTRONG SJ, PLAHTA WC, XU H, DAVIDGE ST: Estrogen improves cardiac recovery after ischemia/reperfusion by decreasing tumor necrosis factor- $\alpha$. Cardiovasc Res 69: 836-844, 2006. 